\title{
12
}

\section{Engineers and Scientists as Commercial Agents of the Spanish Nuclear Programme}

\author{
Joseba De la Torre, M. d. Mar Rubio-Varas, \\ and Gloria Sanz Lafuente
}

\begin{abstract}
Within the framework of the Cold War, the military and civil uses of the atom became the largest technological, socio-political and economic impact on both sides of the Iron Curtain. The unique nature of the technological, financial and managerial decisions about the civil uses of nuclear power granted a leading role to engineers and scientists employed
\end{abstract}

\footnotetext{
The original version of this chapter title was revised to Engineers and Scientists as Commercial Agents of the Spanish Nuclear Programme.

The correction to this chapter is available at https://doi.org/10.1007/978-3-319-75450-5_15

Acknowledgements: the Spanish Ministry of Economy and Competitiveness (project ref. HAR2014-53825-R) and the European Commission and Euratom research and training programme 2014-2018 (History of Nuclear Energy and Society (HoNESt), grant agreement $\mathrm{N}^{\circ} 662268$ ) financed parts of the fieldwork required to compile sources for this chapter.
}

J. De la Torre • G. Sanz Lafuente

Economics Department, Universidad Pública de Navarra (UPNA), Pamplona, Spain

M. d. M. Rubio-Varas ( $\bowtie)$

INARBE, Universidad Pública de Navarra (UPNA), Pamplona, Spain e-mail:mar.rubio@unavarra.es 
by the state and private companies. ${ }^{1}$ That was the case in the USA as it rose to dominate the Western market for nuclear reactors by the mid1960s. Engineers and scientists also played a crucial role in other advanced economies such as Germany when they began to scout out the sector. But what about underdeveloped economies? We aim at analysing the role of engineers and scientists as agents of economic modernization in Spain, which at the time was an underdeveloped economy ruled by an authoritarian regime.

The Spanish nuclear law of 1964 responded both to the pressure of the private electricity companies to procure the nuclear business for themselves and to the industrialization strategy propelled by the dictatorship. ${ }^{2}$ A handful of modernizing engineers and scientists were decisive in the process. Presas, ${ }^{3}$ as well as Camprubi, ${ }^{4}$ unveiled the key role of Otero Navascués who was directing the Nuclear Energy Board projects. We know far less of the other engineers and scientists who joining international networks, transferred technological/scientific knowledge and trained qualified teams within Spain. They also acted as commercial agents. Acquiring foreign atomic technology required specialized knowledge in order to decide which of the different alternatives available in the market to choose. Engineers and scientists stayed at the core of all commercial negotiations and transactions involving nuclear technology. One of their basic tools was the cultivation of good relationships in order to influence institutions, industry, experts and especially policymakers, who had the last word. Finally, the history of the nuclear programme was determined by a very small group of people for whom mutual knowledge and trust were essential. Making use of new archival sources, ${ }^{5}$ this chapter identifies some of these actors, in particular the Spanish industrial engineers Jaime MacVeigh and Manuel Gutiérrez-Cortines and the German scientist Karl Wirtz. These three actors played a strategic role in promoting the Spanish nuclear programme. But in order to understand the role played by these engineers, we first introduce the global market for nuclear reactors from the 1950s to the 1980s and explain that Spain became the principal market for the major international manufacturers of nuclear reactors during the decade between the mid-1960s and the mid-1970s. 


\section{The Global Market for Nuclear Reactors 1950s-1980s: Spain as a Major Client}

On 20 December 1951, electricity was first generated from nuclear power at the EBR-I (experimental breeder reactor I) in Idaho, USA. ${ }^{6}$ Yet the beginning of civil nuclear power is commonly set at President Eisenhower's address to the General Assembly of the United Nations on 8 December 1953, later called the 'Atoms for Peace' speech. ${ }^{7}$ Most civil nuclear programmes around the world began and grew from the 1950s to the 1970s. The first nuclear reactors connected to the electricity grid-Obninsk in the Soviet Union by 1954, Calder Hall in the UK by 1956 and Shippingport in the USA by 1957 - proved the concept, but were far from being commercially viable. They were small (5 MW, $50 \mathrm{MW}$ and 90 MW respectively), each applying dissimilar technologies and with plenty of unknowns to be solved. Eventually, three types of reactors were commercialized internationally. The light water nuclear power reactor, using low enriched uranium as its fuel and ordinary water as its coolant and moderator, was built originally to a US design in Western countries and to a similar Soviet design in the USSR and Eastern European countries; The gas graphite reactor using natural uranium as its fuel, moderated by graphite and cooled by carbon dioxide, was a technological design favoured by the UK and France. Finally, Canada marketed a quite different nuclear power reactor using natural uranium as its fuel and heavy water as its coolant and moderator. In the end, it was the light-water reactor promoted by the USA that was triumphant over the more expensive gascooled reactors built by the British and the French in the 1950 s. $^{8}$

However, until the introduction of 'turnkey projects' in the nuclear business in 1962, with a bid for the construction of a plant at Oyster Creek, New Jersey, the commercial market for nuclear reactors remained stagnant. So did the international market: a total of ten reactors were ordered internationally up to 1964 , with a few other reactors domestically ordered and under construction in the USA, the UK and the USSR. The turnkey plants were offered by the nuclear reactor building companies at a guaranteed fixed price, set in advance, competitive with coaland oil-fired alternatives. Even if in the long term it proved to be a bad 
business, in which the manufacturers lost money, ${ }^{10}$ turnkey projects propelled domestic and international sales of nuclear reactors. Up to 1975 , some 245 commercial reactors had begun to be built around the world in the thirty or so countries that decided to pursue nuclear energy. Of those, almost one hundred were ordered and were beginning to be built in the USA alone. All the US reactors were domestically built by five American manufacturers (General Electric, Westinghouse, Babcock \&Wilcox, Combustion Engineering and Atomic General).

Just over one hundred reactors were ordered internationally (including Soviet sales to Eastern countries). General Electric and Westinghouse captured, with the help of US economic diplomacy and the financial assistance of the Export-Import Bank, almost $80 \%$ of the international sales of nuclear reactors to the Western countries up to the mid-1970s. During the second half of the 1970s, other Western manufacturers, which had been gaining experience by building nuclear plants in their countries, came to compete in the international market, mostly the German Kraftwerk Union, the French Framatome and the Canadian AECL. The British mostly failed to market their Magnox reactor to the world, while the Russians imposed their technology on the Eastern Bloc. By 1975 , the curve of orders had already passed its peak in the USA. ${ }^{11}$ Worldwide, 1976 marked the historical maximum of nuclear power plants beginning to be constructed, with building works being initiated for forty-three new nuclear plants. ${ }^{12}$ Coincidentally, 1976 also saw the last governmental authorization for a new nuclear power plant in Spain.

As an early adopter of nuclear energy, by 1973 Spain already ranked third among countries, with the largest share of nuclear electricity over total electricity produced and being the seventh largest producer in the West. ${ }^{13}$ In fact, over the first half of the 1970s, the Spanish electricity utilities became the largest nuclear clients of world nuclear manufacturers, just ahead of Japan and South Korea. ${ }^{14}$ All the major international nuclear companies attempted to break into the Spanish market, which was the fastest growing nuclear power developer in Europe at the time. ${ }^{15}$ The remainder of this chapter aims to expose the role that engineers and scientist played in helping the destitute, internationally ostracized and dictatorial country that was Spain become a relevant player in the global nuclear market. 


\section{Nuclear Optimism and Energy Planning by Entrepreneurs and Engineers: MacVeigh and Cortines as Atomic Leaders}

In Spain, experience in managing large engineering works, handling credit and establishing contact with the USA and European firms enabled the electrical lobby to take on the nuclear programme. Since the 1940s, the electricity companies had built up groups that comprised highly skilled engineers who were used to collaborating with foreign experts on large engineering projects. Some industrial engineers became the true architects of the Spanish nuclear strategy, taking on the functions of business leadership, project management, public dissemination of energy policy and the orchestration of a lobby. This is our main hypothesis. These engineers had first-hand knowledge of what the USA had been doing since 1945, but also knew of the limitations of Spanish industrial capacities. They frequented the meetings of the Atomic Industrial Forum in New York and reacted to the business expectations that were put forward at the 1955 Geneva Conference. Upon return from Switzerland, a group of these industry captains had a meeting with General Franco to convey their objectives the nuclear programme should be the responsibility of private enterprises. ${ }^{16}$ It was unclear at this stage whether the nuclear civil programme was to be a private endeavour in Spain or whether it would continue in the hands of the government's Nuclear Energy Board (JEN). ${ }^{17}$ A British report summarized the situation in early 1957: at least $80 \%$ of the electrical supply industry was controlled by a few private companies in association with the main Spanish banks; the electrical engineering industry was developing on a fairly satisfactory scale stimulated by the demand from state and private power production schemes; the larger utility firms were closely associated with French, German and US firms under patent agreements. ${ }^{18}$ 'The range of small products is increasing rapidly, but there is no plant for production of the massive electrical generating components required in modern base load stations. ${ }^{19}$ The utilities therefore knew their weaknesses and recognized the need to establish strategic alliances. 
The next step entailed the creation of two business consortia to build nuclear power stations in regions that were historically controlled by private enterprises, thus enabling them to distribute a substantial part of the future of the nuclear market and reinforce their unequivocal commitment. The Northern Nuclear Plants SA (Nuclenor: Iberduero and Electra Viesgo) and the Centrales Nucleares SA (Cenusa: Unión Eléctrica Madrileña, Hidroeléctrica Española and Sevillana de Electricidad) for the southern region were founded by electrical and financial entrepreneurs but managed by engineers. ${ }^{20}$

Jaime MacVeigh Alfós (191?-1985), ${ }^{21}$ and Manuel Gutiérrez-Cortines (1901-1980), ${ }^{22}$ were two of them. Both were industrial engineers and had developed contacts with foreign firms. Son of a counsellor of the HispanoAmerican Bank, MacVeigh finished his studies in the School of Industrial Engineers of Madrid in 1943. Between 1945 and 1950, engenieer MacVeigh had a managing role within the Spanish TALGO project (Tren Articulado Ligero Goicoechea Oriol, Goicoechea-Oriol light articulated train). The construction of the famous articulated train was made in conjunction with American Car \& Foundry, taking MacVeigh to some of the nuclear industry sites in Pennsylvania, Delaware and New Jersey. Upon his return to Madrid, he abandoned TALGO and was hired by the Banco Urquijo. MacVeigh went on to specialize in nuclear projects, convinced that they offered 'the solution to Spain's electric problem'. ${ }^{23}$ Cortines, in the other hand, was managing director of Standard Electric in Spain and Portugal before the civil war. From 1940, he worked as counsellor in Electra Viesgo, one of the future partners who built Garoña nuclear power plant (NPP) in the 1960s.

Between 1956 and 1962, MacVeigh and Cortines, as technical advisors and counsellors for Cenusa and Nuclenor respectively, developed a very long-term expansion strategy. Together with the most significant executives of the electric companies, both engineers participated in the Assessment Commission of Industrial Reactors (CARDI) at the Spanish Nuclear Energy Board (JEN), where they established alliances with scientists, experts and businessmen. ${ }^{24}$ MacVeigh's public presence had been constant since 1955, spreading the idea that Spain should bet on the economy of the atom. His political and business contacts abroad allowed him to know precisely the technological advances that were being made in the USA and in Europe. Indirectly these two engineers contributed to 
the turn of the governement's industrial policy that left the business of nuclear power plants in the hands of private firms. In short, these two men become a turning point in the commitment to nuclear power and in the maturation of an industrial sector that was unprecedented in Spain. In 1957, MacVeigh collaborated in founding the nuclear engineering company Técnicas Atómicas (Tecnatom SA). ${ }^{25}$ Through this company, MacVeigh directed and led the project of the first Spanish nuclear plant on the Tajo river, at Zorita, and meanwhile Cortines initiated the drafts for the so-called Ebro-Bilbao nuclear power station. Simultaneously both leaders networked with the national atomic agencies of the USA and the UK, as much as with the chief multinationals in the atomic business. Last but not least, they negotiated contracts with international banks and suppliers and supervised the building process once it began. They shared learning and commercial trips. As Cortines wrote some years later, one of the reasons why the Spanish programme had adopted three different technologies was the negotiations undertaken by each company. Each reactor belonged to a different utility and 'all of them were offered under excellent economic conditions'. ${ }^{26}$

Why this passion for nuclear energy? Firstly, because it was a political decision, 'Atoms for a dictatorship'. ${ }^{27}$ Francoism embraced the nuclear programme for military and economic reasons. Nevertheless, and secondly, we believe that it was possible not only because of the times of atomic optimism in which the Geneva Conference opened, but also because it was technologically one of the main challenges for engineers of the mid-twentieth century. And of course, the electrical utilities saw a business opportunity to conquer and, in Spain, they had excellent political contacts through which to do this. In this sense we can understand why the first non-governmental technical/economic report on the need to incorporate nuclear energy into the Spanish energy matrix was produced by the Research Service of Banco Urquijo, an industrial bank with important interests in electricity, in February $1957 .{ }^{28}$ Entitled 'Essay on a nuclear programme for Spain' (Ensayo sobre un programa de energía nuclear en España) and written by Jaime MacVeigh, it concluded that before 1970 Spain would face a major deficit of traditional electricity generation that could only be offset by introducing nuclear power. Given the urgent need to meet the excess demand, MacVeigh urged in his essay 
that work should start on the first commercial nuclear power plants no later than 1964 and continue after that at an exponential rate. ${ }^{29}$ MacVeigh's hypothesis on the growth between $5 \%$ and $7 \%$ annual of the Spanish electric demand from 1950 to 2000 proved to be excessively conservative in the short and medium term, although remarkably precise in the long term. His nuclear projections, however, were extremely optimistic. At the height of the Spanish nuclear programme, in the final phase of the dictatorship between 1971 and 1976, the installed capacity would never have exceeded 33 GW if all the projects that the utilities applied for had become operational. ${ }^{30}$ This engineer knew the obstacles that a project such as the one he was proposing would have to face. MacVeigh recognized that the technical problems had been solved but the economic ones had not. ${ }^{31}$ The report from the Urquijo Research Service admitted that the cost of nuclear $\mathrm{kWh}$ produced at commercial nuclear power plants at that time was no less than twice the current fossil fuel costs. MacVeigh further stated in his essay that the order of magnitude of investments in nuclear power plants from 1965 to 2000 would have to be between 150 and 280 billion pesetas of 1955 (from $\$ 14$ to $\$ 25$ billion at the official exchange rate). That was excluding the additional facilities that a nuclear programme would entail. Including those, the full development of the programme could account for $25-40 \%$ more. ${ }^{32}$ In other words it was a great opportunity to do business and to promote the industrialization of the country.

MacVeigh, Cortines and other businessmen and technocrats were invited to visit the British nuclear installations in 1957. Although in the end the British did not get any atomic contracts from Spain, this contact was very important for the utilities' managers. For instance, a report titled 'Training and Construction Programme for a Nuclear Power Project in Spain' summarized what should be the process of training a team of engineers to build an atomic plant. In 1958, MacVeigh conducted a training course for senior executives that would be very useful in the Zorita project. Briefly, and according to the British experts, the most important consideration was to nominate at the earliest possible moment the chief engineer for the whole project, since this training would be of long duration, and he must be allowed to choose his own staff. The requirements for the chief engineer were that he should have considerable experience in 
construction of conventional power station plants, as well as strong technical and administrative ability to draw up enquiries for tenders and to supervise construction of the plant. During the first year, the chief engineer's main task would be to recruit his team and to start its training at the Hartwell Reactor School and with the Calder construction teams. The complete team would contain a similar number of engineers experienced in conventional power station practice, covering such areas as turbines, alternators, instrumentation and switchgear. The chief engineer would pay visits to the industrial firms from whom tenders were being sought and would also spend some time at the research station operated by JEN in Spain and the UK Atomic Energy Authority (UKAEA). Construction could be started within three months of planning an order and should be in operation about three-and-a-half years afterwards. The chief engineer would supervise construction and ultimately operation of the station, and he would supervise the contractors with the assistance of his design engineers, the operation superintendent and the maintenance engineer. ${ }^{33}$ Eventually, MacVeigh as chief advisor of Tecnatom would apply this very same strategy in the first plant that was built in Spain, but using American firms instead.

On a commercial mission to England in 1960, MacVeigh made a relevant situation diagnosis. His company's plans relied on the government's opinion. He believed that the Spanish industry could participate in a conventional power station by manufacturing turbines, instrumentation, alternators and steam raising equipment, but excluding the fuel cycle. For this reason, he considered the JEN trials to be a big mistake. MacVeigh declared himself a supporter of the plan to import the reactor and stated that he was familiar with the US financial facilities. To achieve this, it was necessary to influence the decision-makers. Gutiérrez-Cortines personally told Minister of Industry Joaquín Planell that the companies 'doubted whether the government intended allowing the private utilities to build nuclear stations'. The answer was 'the Government would support [...] at the appropriate time'. ${ }^{34}$ The problem, in fact, was that the people in charge of the autarkist policy were still in their posts and did not understand the meaning of the new economic policy. By late 1961, MacVeigh was more forceful in his strategy and drafted a confidential report wherein he was critical of the policy of the JEN and its President. ${ }^{35}$ This report 
was given to López Bravo, manager director of Spanish Foreign Currency Institute (IEME), and soon after to become Industry Minister. In MacVeigh's opinion, JEN's plan to proceed with the experimental projects was illusory and expensive. Moreover, the fuel cycle would not be viable until 1970 and would be hardly able to cover the needs for uranium; this would delay the rollout of the power stations. Therefore, MacVeigh's report advised supporting the private initiative that was prepared to immediately construct 'a small and standard plant with a future'; it would be of the 'boiling water' type and come at a 'reasonable' cost. Those running the Zorita project firmly believed that they had to speed up the nuclear race by using US technology and collaborating with the Spanish private companies. MacVeigh was right to consider that everything depended on two essential factors: 'the capacity of Spanish industry' to respond to this challenge and 'the (economic) liberalisation' that access to the foreign market would provide. ${ }^{36}$ No doubt MacVeigh knew whom he was addressing. López Bravo-'Mr. Efficiency' as he was nicknamed by a well-known banker-would have all the authority and the last word in awarding the nuclear programme and the tenders. IEME's manager was responsible for liberalizing the foreign currency market and foreign transactions, and as the Minister of Industry promoted an industrial policy that was favourable to foreign capital in general terms, and to American firms in particular.

Furthermore, Cortines and MacVeigh collaborated in founding the Spanish Atomic Forum (Fórum Atómico Españo, FAE) at the end of 1961. FAE became the Spanish nuclear lobby, since it was an alliance of industries that sought a market niche in nuclear energy: steel, metal-mechanical, shipbuilding, chemical and electronic companies, in addition to electricity producers and distributors and engineering and consulting firms. FAE had the support of public and semi-official entities and became part of the European Atomic Forum (Foratom), a necessary link for its internationalization and for complying with nuclear safety regulations. In addition, as vice-presidents of the lobby, MacVeigh and Cortines were counted among the instigators of the project for a European fast fusion reactor, necessarily encountering scientists and the atomic business ecosystem in Europe and North America. In fact, FAE and the Spanish Nuclear Board organized several meetings with French, British, North American and Western German industries during the 1960s. 
It should be noted that Spanish industry did not start from zero. The experience gained in conventional thermal power plants, at least since 1950, had allowed engineers to conduct major projects and develop mechanical and electrical assembly techniques. In addition, the factories making specialized machinery and auxiliary equipment for the generation and industrial use of electricity, sometimes with foreign patents, had benefited from manufacturing growth during the 1950s. ${ }^{37}$ The nuclear programme was identified as an opportunity. These companies had to innovate in product, techniques, knowledge and management. The manufacture of capital goods and industrial assemblies requires large-scale engineering and consulting services. Some of these firms were born at the time and others, which already existed, adapted to the new challenge by diversifying their production lines and building up strategic links with foreign companies. This was a way in which to solve the two great shortcomings of the Spanish companies: capital and knowledge. In MacVeigh's words, nuclear participation meant 'improving, in general, its construction and productivity standards. ${ }^{38}$ The challenge was to build the first nuclear power plants. Zorita and Garoña were the litmus test for MacVeigh and Cortines.

While Cortines served as an executive officer, ${ }^{39}$ MacVeigh acted as a chief engineer with some additional management functions. Even though Cortines referred to Garoña as 'my nuclear plant', the execution of the contract was the direct responsibility of the American multinational. General Electric coordinated, controlled and subcontracted all phases of the project through its subsidiary GE Technical Services Co. (GETSCO). So Cortines negotiated capital goods contracts and financial credits, but was not directing the works. On the contrary, Westinghouse Electric International and its subsidiary Westinghouse Atomic Power of Spain relied on Tecnatom, the Spanish consultancy directed by MacVeigh, to supervise the entire Zorita's project of engineering and management. Why did WEICO confer so much responsibility on a local consulting firm that GE disregarded? In 1965, Tecnatom was only a little company, with a small but highly qualified staff, and with more theoretical knowledge than experience in atomic technology. It is true that Garoña was triple the size of Zorita, which made the project more complex. GE had to consider, with good reason, that the Spanish engineering and consultants were still 
at an embryonic stage, considering the degree of specialization, technical assistance and learning that were required. Our hypothesis is that the main intangible was embodied in the figure of the advisor-delegate MacVeigh, the project leader who had worked in USA, communicated well in English and personally knew WEICO and also possessed the knowledge and contacts to operate in a complicated country such as Franco's Spain. With all this, MacVeigh could convince the Americans and the policymakers and impose his criteria. MacVeigh put into practice a very personal management structure in Zorita NPP. He negotiated import licences and dollars with the Spanish authorities and contracted logistics in Europe or the USA for the transport of the vessel and the reactor. He also supervised the exit and return of the Spanish uranium to be enriched in America, and agreed loans with public and private banks abroad in a variety of different currencies. ${ }^{40}$

Once the power plant programme was in place, the Minister of Industry gave priority to the future fast breeder reactor. López Bravo again sought the support of the JEN and the nuclear industry. MacVeigh and Cortines also played a key role. On this occasion, they sought to approach European partners and use their old networks in the UK, France and West Germany. The point of connection was the supply of uranium for Zorita NPP. At least since 1962, the UKAEA and Tecnatom had held meetings and negotiations on this issue. According to a British memorandum of September 1968, the Spanish government was very interested in advancing this new technological development. The Energy Director in the Ministry for Industry, 'who is from private industry', expressed that Spain needed nuclear power and the fast reactor seemed the most promising way of obtaining it. He asked about the British plan and requested a visit to the Dounreay installations. Some days later MacVeigh confirmed his own interest in the fast breeder. 'He knew in outline' of the British proposal for Spain and confessed that the American Betchell were 'very impressed indeed with the British fast reactor position and were convinced' that 'it would be adopted in the USA'. MacVeigh 'was personally prepared to back it and recommend his organisations, Tecnatom and UEM, to put money into it'. The report concluded by stating that 'as you know MacVeigh is an influential man in Spain and is a very good friend of ours'. ${ }^{41}$ 
However, MacVeigh's time at Tecnatom was running out. This consulting engineering company had been created to build Zorita. Once completed and connected to the network in 1969, Tecnatom entered a phase of uncertainty. The board of directors was given a two year trial period, after which its future would be evaluated, not excluding the possibility of dissolving the company. This situation was perhaps decisive in MacVeigh's decision to leave the company in late 1969. ${ }^{42}$ Banco Atlántico hired him, a firm linked to the finances of Opus Dei and expanding its industrial businesses. Meanwhile, Cortines acceded to the presidency of the Spanish Atomic Forum and to the council of the European Forum, and tried to advance the development of the fast reactor with partners in Europe and America.

\section{From Scientific Knowledge to Entrepreneurial Ecosystem: Karl Wirtz and the Spanish Atomic Programme}

The technological and financial challenges entailed by atomic development led to the early appearance of international projects during the 1950s. The idea was to share experiences, costs and financial risks in this new sector, which still had uncertain technological potential. Karl Wirtz, one of the scientists behind the atomic bomb of Hitler's Third Reich, had been considered 'an old friend of Spain' by the JEN since at least 1949. Private firms, entrepreneurs, diplomatic services and political decisionmakers played an important role in shaping the Spanish atomic network between the 1950s and 1970s. However, no national or international atomic programme can be understood from reductionist approaches that refuse to interrelate politics, technology, commerce and culture. ${ }^{43}$ Nor can such a programme be explained by one sole actor. In contrast, only an investigation of the connections between all social spaces and multiple actors enables the development of a historical explanation. In addition, these actors moved in substantially different political and economic contexts. We need only mention the political distance between Franco's Spain and the economic development policy of the Federal Republic of Germany(West Germany), a country that was democratic, industrialized and fully integrated into Europe. 
If we adopt the day-to-day activities of a sales department manager as our point of reference, Karl Wirtz was not, strictly speaking, a sales representative. He was not in charge of managing private businesses. He was not authorized to negotiate contracts or credits. He did not define distribution channels or set prices, loans or interest charges for nuclear services and products. Nevertheless, his trips and meetings outside West Germany formed part of a long chain of public and private relationships that shaped the commercial and scientific ties between countries interested in implementing atomic programmes. ${ }^{44}$

From 1972 to 1979 , Wirtz served as an organizer and consultant to the West German federal government regarding the transfer of nuclear technology from West Germany to Spain. The reasons cited for his appointment were his scientific qualifications and his familiarity with the Spanish market. Wirtz's contact with the JEN dated to the creation of the Board, as recalled by Otero Navascués, with whom Wirtz had shared a 'close friendship' since 1949. But who was Karl Wirtz (1910-1994)? Receiving his doctorate in physical chemistry in 1934 as a heavy-water specialist, Wirtz had completed his academic training in the tumultuous context of the purge of Jewish scientists and any other scientist believed to oppose the Nazi dictatorship. In 1937, he became an assistant at the Physics Institute of the Kaiser Wilhelm Society. As late as September 1939 he maintained international contacts with British and American colleagues, which the war would later end. ${ }^{45}$

'I have done that.' 'I conducted the negotiations with the firms.' 'I have done the experimental work.' These were statements that Wirtz made sure he emphasized during the Farm Hall interrogations. A cottage located near Cambridge in England, Farm Hall was the internment centre to which Wirtz was taken in 1945 with the other scientists who had worked on the Third Reich's atom bomb project. Werner Heisenberg, Otto Hahn and Carl Friedrich von Weizsäcker all spent time there. Ambition, lack of humility and a combination of scientific skills and the ability to communicate with firms were elements of the image that Wirtz projected of himself. He seemed optimistic as well, stating that the odds of him and his colleagues making a quick return to Germany were 70\%, in contrast with Heisenberg's doubts. Although Wirtz came to believe that he and the others would be taken to the USA to work, in early 1946 
Wirtz and the rest of the group returned to Göttingen in the British occupation zone amidst post-war difficulties and at a time when the city was teeming with refugees. ${ }^{46}$ The scientific reconstruction of Western Germany began before the establishment of West Germany as a state (1949). For example, the Max Planck Society was formed in the British zone in September 1946 and authorized in the other zones in 1948. ${ }^{47}$ Albeit with difficulties, German nuclear scientists resumed their international relationships quickly during the formative years of the international nuclear community. Wirtz underwent a rapid denazification process and travelled to Brighton in September 1948 for the annual meeting of the British Association for the Advancement of Science. In 1949, he was invited to visit the University of Melbourne (Australia). He spent the last few months of 1950 in Argentina invited by the Nuclear Energy Commission of that country, reestablishing contact with former colleagues there who would later return to West Germany. Thanks to the efforts of the French chemist Bertrand Goldschmidt, and not without causing tensions, Wirtz attended a conference on reactor technology in Kjeller (Norway) in 1953. There he met Alwin Weinberg of the American Oak Ridge National Laboratory. In fact, he never cut ties with his former colleagues who joined the American scientific system, and he made his first trip to the USA in 1955 . He returned a year later, joined by the head of the DEMAG corporation, which merged with Atomics International to form the Interatom corporation. ${ }^{48}$

Wirtz's international presence played a part in the first Adenauer government's interest in the nuclear economy, despite the fact that the Paris Accords, along with other legal measures, prohibited nuclear production and research in Germany for civil and military uses until 1955 and the enrichment of uranium until 1960. ${ }^{49}$ The initial relationships and exchanges created shared social spaces for industrialists and scientists, such as the Society for the Study of Physics (Physikalische Studiengesellschaft, PSG) founded in Düsseldorf in 1954. Although he had already started to form a group of young scientists and engineers in Göttingen, Wirtz leveraged the PSG to assemble a reactor research group, which he moved to Karlsruhe. ${ }^{50}$ As a professor and director of the Institute for Neutron Physics and Reactor Technology, he later presided over the scientific council of the Karlsruhe Nuclear Research Centre (Kernforschungzentrum Karlsruhe, 
KfK) in Baden-Württemberg until 1978, an institution that with the Jülich Research Centre (Kernforschungsanlage Jülich, KfA) in North RheinWestphalia was one of two scientific, academic and incubator sites for research and development in this sector. ${ }^{51}$ The advances that emerged from the KfK included a new uranium enrichment technology similar to Erwin W. Becker's nozzle process, and utilized by the Steag AG Corporation, and a system for monitoring fuel movements, which was conceived by Wirtz and enhanced by Wolf Häfele. From 1956 to 1971, Wirtz was a member of the German Atomic Commission, and he directed that agency's 'reactor circle' until 1966. He also contributed to designing Germany's first and second atomic programmes. The relevance of this complex institutional, public and private framework lies in the implicit, constant cooperation it represents between the scientific system and the firms that shared the strategic objective of internationalization despite conflicts over development and financing. ${ }^{52}$

In this historical context, Wirtz came to play the role of mediator between scientific institutions and nuclear firms in Spain and West Germany, although Spain was not the only hub of his international activity. The first step along this path consisted of academic collaboration. Relationships with Spain were resumed immediately after the war in Göttingen to enable Spanish physicists to research their doctoral theses. ${ }^{53}$ Otero Navascués travelled there in 1949, having taken an interest in the German pioneers of reactor technology. In March 1950, the newspaper Die Welt reported that Wirtz would travel to Madrid at the request of the Franco government to assist in the establishment of a cosmic radiation laboratory. The article was referring to the future research centre of the JEN in Moncloa, which was intended to replicate the UK's Harwell centre and France's Saclay centre. ${ }^{54}$ Additionally, Wirtz was one of the first foreign lecturers at the Applied Nuclear Physics Course organized by the Spanish National Research Council (Consejo Superior de Investigaciones Cientificas, CSIC) between November 1950 and July 1951. According to Aschmann, the interest of the National Institute of Industry (Instituto Nacional de Industria, INI) in acquiring German scientific and engineering know-how figured in the background of that first trip. ${ }^{55}$ In fact, Manuel Espinosa Rodriguez, former naval attaché to the embassy in Berlin, travelled to the three Western occupation zones to rekindle former 
relationships and recruit specialized technicians. To this end, Lieutenant Ignacio Moyano wired approximately US \$30,000 from the Spanish Institute of Foreign Currency (IEME) to the Bank Deutscher Länder in Frankfurt. Ten scientists expressed interest, including Wirtz. ${ }^{56}$ In the 1950s, Wirtz made additional trips to Spain and corresponded with Otero Navascués, Maria Aranzazu Vigón, Carlos Sanchez del Río (JEN) and Romero Ortiz (Geological and Mining Institute). ${ }^{57}$ At the foundation established with JEN, Spanish scientific experts, politicians, and commercial managers started to closely interact in atomic programmes and national and international forums. During the early stages, the search for uranium and other nuclear fuel was prioritized. Later, between 1955 and 1960, Wirtz advised JEN on test reactor development, arguing in favour of natural uranium to avoid dependence on the American monopoly on enriched uranium, just as France, the UK and West Germany were seeking to do. Wirtz also negotiated with the German Nuclear Affairs Ministry to obtain financing for JEN. In 1958, he attended the inauguration in Moncloa of the experimental reactor acquired from GE. ${ }^{58}$

Wirtz recognized that his interventions in the 1950s were showing results in the scientific realm but that he would only begin to prosper in commercial terms in the long run, specifically in the 1960s. However, Spanish-German relations weakened in the early 1960 s primarily because German industry remained incapable of exporting a nuclear power plant. A secondary reason for these weakened relations was likely the fact that the main atomic products at the time, power plants, were controlled by multinationals from other industrial powers. In Spain, while Vandellós was a French project, Zorita and Garoña were the work of American corporations, WESCO and GE, where MacVeigh and Cortines were pioneering the nuclear business in which they would eventually meet Wirtz.

During this period of nuclear optimism, improving the technological capacity of reactors and ensuring a sufficient fuel supply posed new challenges. Thus the fast reactor and the fuel cycle occupied a substantial portion of the scientific, diplomatic and commercial nuclear agenda in the USA and Europe. In fact, Wirtz and Häfele expressed their scientific interest in advanced, or fast, reactor prototypes at the KfK beginning in the late 1950s. Such prototypes were not exclusively a German development 
but were included in the scientific plans of the leading nations. In 1960, financing for the project was approved by the German Atomic Commission. The effort's financial and technical complexity required multilateral collaboration and support from the European Atomic Energy Community (Euratom). ${ }^{59}$ Another business opportunity that drew together scientific research and the nuclear industry was the fuel cycle. Amidst rapid expansion, progress had to be made in enriched uranium manufacturing for existing power plants and particularly for future technologies for electronuclear production, an essential process subject to the US and Soviet duopoly of that time.

The fast breeder and nuclear fuel manufacturing had been prominent among the concerns of Minister of Industry Lopez Bravo since at least 1966, and these matters were addressed by G. Soltenberg and Otero Navascués during their visit to the uranium mines of Andújar that year. ${ }^{60}$ At that time, there were already Spanish scientists in the KfA and the KfK in West Germany. The correspondence between Wirtz and Sanchez del Rio, the head of JEN's Nuclear Physics and Chemistry Division, reveals their close collaboration on the fast breeder. ${ }^{61}$ In 1968, Wirtz travelled to Madrid with five collaborators to manage JEN's participation in the Projekt Schneller Brüter (PSB). ${ }^{62}$ This scientific and technical cooperation was extended in $1970 .{ }^{63}$ However, JEN was not the only organization involved in the project. The PSB had also attracted Unión Eléctrica Madrileña, SA (UEM), the developer of the Zorita nuclear power plant and its expansion. Wirtz kept in touch with the old MacVeigh circuit in Tecnatom and UEM. ${ }^{64}$

The second entry point to the atomic entrepreneurial ecosystem was nuclear fuel manufacturing. A September 1968 entry in Wirtz's travel diary described at length his contacts with the leadership of JEN, making note of the individuals he referred to as 'Mir wichtiger Industriemänner', that is 'men of industry who are important to me': López Bravo, Cortines, Oriol, Urquijo, Kaibel, Sendagorta, Mendoza and Millán, among others. In institutional terms, this list referred to the Ministry of Industry, the Atomic Forum and several of the firms involved in nuclear projects: Ibernuclear, Hidroelectrica Española, Sener Consulting, the Spanish Society for Naval Construction, Unesa and Babcock \& Wilcox Spain. Wirtz added: 'López Bravo has influence over Cortines' decision about 
fuel manufacturing.' The scientist was well informed. The minister's efforts resulted in the creation of Ibernuclear, a mixed partnership (70\% private and $30 \%$ public) that was managed by Cortines, 'the most important man at the time'. ${ }^{65}$ This partnership was placed in charge of site studies for a fuel plant for light water natural uranium reactors ${ }^{66}{ }^{6 n}$ fact, Cortines had contacted Heinrich Mandel of the West Germany electricity utility Rheinisch-Westfälisches Elektrizitätswerk (RWE) and visited Wolfgang, the headquarters of Schimmelbusch's NUKEM (NuklearChemie-Metallurgie). ${ }^{67} \mathrm{He}$ also visited the headquarters of the KfK, where he was joined by the head of the UEM, Julio Hernández Rubio. ${ }^{68}$

Under the mandate of López de Letona, the Ministry of Industry, the INI and the electricity utilities promoted the National Uranium Enterprise (Empresa Nacional del Uranio, ENUSA) as a fuel manufacturer and expanded contacts with foreign industries that possessed that technological capacity. Such was the case with the Kraftwerk Union (KWU). Product of a merger of the reactor departments of the Allgemeine ElektricitätsGesellschaft (AEG) and Siemens, KWU began to submit bids in 1969 to construct reactors in international calls for tenders and presented offers in Spain for the nuclear power plants in Almaraz, Lemoniz, Ascó and Cofrentes. Managers led these international relationships. However, they did so in close communication with the diplomatic services and institutions such as the KfK through the Society for Atomic Research (Gesellschaft für Kernforschung, GfK). ${ }^{69}$ The first agreement between the GfK and JEN was signed in Madrid in 1973. Foreign Minister López Rodó and Wirtz were in attendance, along with Greifeld (GfK), Sánchez del Río, Oltra (JEN) and representatives of Interatom, which still belonged to KWU. ${ }^{70}$ However, the challenge of obtaining an important nuclear contract in Spain would remain unmet until 1975. Although Wirtz was not the decisive actor, he represented an important player in a complex process that would eventually enable KWU to construct the Trillo nuclear power plant, the only such plant to be built by a German corporation in a booming market that was practically monopolized by American firms. ${ }^{71}$ A 1976 letter to the KWU president in which Wirtz offered contacts in Galicia to help KWU win the call for tenders for the Regodola nuclear power plant reveals that the context had changed..$^{72}$ By the mid-1970s, business managers had become the key decision-makers in megaprojects. 
Not every decision passed through Wirtz, and not all interventions were rewarded with success. However, his work as an enduring catalyst of public and private relationships in the international nuclear community was crucial in the rapprochement between German and Spanish firms and scientific institutions in the nuclear field. A bridge between nuclear scientific knowledge and the Spanish and German entrepreneurial ecosystems, Wirtz made these connections part of his career and his activity with the $\mathrm{KfK}$. He did so at times without complete information and aware of the limitations through collecting data and contacts, linking evidence and fostering trust. How did he do it? By introducing himself into the lines of communication between key industrial actors and political decision-makers in Spain, by writing reports that he distributed to leaders of industry, politicians and scientists, providing information and his impressions of these meetings, and by constantly promoting scientific cooperation.

\section{Notes}

1. Balogh, B.: Chain Reaction: Expert Debate and Public Participation in American Commercial Nuclear Power, 1945-1975. Cambridge: Cambridge University Press, 1991.

2. De la Torre, J. and Rubio-Varas, M. d. M.: 'Nuclear Power for a Dictatorship: State and Business involvement in the Spanish Atomic Program, 1950-85', Journal of Contemporary History, Vol. 51. No.2 (2016) 385-411.

3. Presas, Albert: Science on the periphery. The Spanish reception of nuclear energy: An attempt at modernity? Minerva, No. 43, Iss. 2 (2005), p. 197-218.

4. Camprubí, L.: Engineers and the making of the Francoist regime. Cambridge, MA: MIT Press, 2014.

5. Through this chapter we make use of materials from the following archives: Archivo Histórico de la Sociedad Estatal de Participaciones Industriales [ASEPI] (Madrid, Spain); Archivo Histórico del Banco de Bilbao Vizcaya Argentaria [AHBBVA] (Bilbao, Spain); Export-Import Bank Archives [EXIM] (College Park, Maryland, USA); Generallandesarchiv Karlsruhe [GLA] (Karlsruhe, Germany); Politisches Archiv des Auswärtigen Amts [PA AA] (Berlin, Germany); The National Archives of United Kingdom [TNA] (Kew, United Kingdom). 
6. Rubio-Varas, M. d. M. and De la Torre, J.: 'How did Spain become the major U.S. nuclear client?', In Rubio-Varas, M. d. M. and J. De la Torre, (eds.), The Economic History of Nuclear Energy in Spain: Governance, Business and Finance. London: Palgrave Macmillan, 2017, pp. 116-54.

7. Eisenhower, Dwight: 'Atoms for Peace Speech', 1953. Available at: https://www.iaea.org/about/history/atoms-for-peace-speech. See also Drogan, Mara: 'The Nuclear Imperative: Atoms for Peace and the Development of U.S. Policy on Exporting Nuclear Power, 1953-1955', Diplomatic History, Vol. 40, No. 5 (2016), pp. 948-74.

8. United States, General Accounting Office, Comptroller General Report to the Congress, 'U.S. Nuclear Non-Proliferation Policy: Impact on Exports and Nuclear Industry Could Not Be Determined', Washington D.C: US Government Printing Office, 1980, pp. 8-9.

9. Rubio-Varas, M. d. M. and De la Torre, J.: 'Spain-Eximbank's Billion Dollar Client: The Role of the US Financing the Spanish Nuclear Program', in Beltran A., Laborie L., Lanthier, P. and Le Gallic, S. (Eds.), Electric Worlds / Mondes électriques: Creations, Circulations, Tensions, Transitions (19th-21st C). London: Peter Lang, 2016, pp. 245-70.

10. Burness, H. Stuart, Montgomery, W. David and Quirk, James P.: 'The Turnkey Era in Nuclear Power', Land Economics, Vol. 56, No. 2 (1980), pp. 188-202.

11. Cohn, S.: Too Cheap to Meter: An Economic and Philosophical Analysis of the Nuclear Dream, New York: State University of New York Press, 1997, p. 127.

12. International Atomic Energy Agency (IAEA): Nuclear Power Reactors in the World, Vienna: IAEA, 2016, p. 79.

13. Central Intelligence Agency (CIA): Nuclear Power and the Demand for Uranium Enrichment Services, Washington: Government Printing Office, 1974. Table 1., p. 4. [CIA Document Number CIARDP85T00875R001900030].

14. Rubio-Varas and De la Torre, 'Spain-Eximbank's Billion Dollar Client', p. 239.

15. Ibidem.

16. Gutiérrez Cortines, Manuel: 'Las centrales atómicas en los programas de construcción de las empresas eléctricas', Conferencia Pronunciada al Círculo de La Unión Mercantil e Industrial de Madrid. Madrid: Círculo de la Unión Mercantil e Industrial de Madrid, 1958. 
17. The Junta de Energía Nuclear (JEN, Nuclear Energy Board) created by the Spanish government in 1951 (springing from preexisting units for atom investigation) generated similar institutional structures for the development of nuclear civil uses as those of other Western governments at the time.

18. TNA. Foreign and Commonwealth Office [FCO). H.R. Jonson, Technical Policy Branch, Notes 7th January 1957).

19. TNA. Foreign and Commonwealth Office [FCO). H.R. Jonson, Technical Policy Branch, Notes 7th January 1957).

20. Romero de Pablo, A. and Sánchez-Ron, J.M.: Energía nuclear en España. De la JEN al CIEMAT. CIEMAT, Madrid: Ediciones Doce Calles, 2001.

21. Valbuena, Pablo: Historia de la Escuela Técnica Superior de Ingenieros Industriales de Madrid desde 1901 hasta 1972. Proyecto fin de carrera (1996). De la Torre, J: 'Who was Who in the Making of Spanish Nuclear Programme, c.1950-1985', In Rubio-Varas, M. d. M. and J. De la Torre, (eds.), The Economic History of Nuclear Energy in Spain: Governance, Business and Finance. London: Palgrave Macmillan, 2017, pp. 33-65.

22. Alzugaray, J.J.: Reflexiones de un ingeniero, Madrid: Eds. Encuentro. 1999, pp. 73-4.

23. This was natural since the financier who promoted the TALGO first and the nuclear bet for Hidroeléctrica Española later was Jose María Oriol y Urquijo. For more on this see Ballestero, Alfonso: José Ma de Oriol y Urquijo. Madrid: Lid, 2014.

24. De la Torre, J., and Rubio-Varas, M. d. M.: La financiación exterior del desarrollo industrial español a través del IEME (1950-1982), Banco de Espańa, Madrid, 2015, pp. 99-105.

25. Álvaro, Adoración: 'The Globalization of Knowledge-Based Services: Engineering Consulting in Spain, 1953-1975', Business History Review 88 (2014), pp. 681-707.

26. Gutiérrez Cortines, Manuel: 'Nuclear Industry in Spain', Nuclear Engineering International 17, no. 188 (1972), pp. 31-32.

27. De la Torre and Rubio-Varas: 'Nuclear Power for a Dictatorship'; Otero Navascués, José Ma: Nuclear Energy in Spain, Nuclear Engineering International 17, no. 188 (1972), pp. 25-28.

28. MacVeigh, J.: Ensayo sobre un Programa de energía Nuclear en España, Madrid: Banco Urquijo, 1957; Puig, N. and Torres, E.: Banco Urquijo. Un banco con historia, Madrid: Turner, 2008. 
29. According to the hypotheses of the essay, nuclear power installed in 1970 should be $0.35 \mathrm{GW}$, peaking by the year 2000 between a minimum of $21 \mathrm{GW}$ and a maximum of $39 \mathrm{GW}$ of nuclear power generation; the equivalent of a minimum of 106 to a maximum of 194 nuclear reactors of 200 MW operating in the year 2000. MacVeigh, Ensayo sobre un Programa de energía Nuclear en España, p. 13.

30. De la Torre and Rubio-Varas, 'Nuclear Power for a Dictatorship'.

31. ABC, 11 April 1956, p. 41.

32. MacVeigh, Ensayo sobre un Programa de energía Nuclear en España.

33. TNA, AB 61105, Notes visit, January 1957.

34. De la Torre, 'Who was who'.

35. De la Torre and Rubio-Varas, La financiación exterior del desarrollo industrial español a través del IEME, pp. 109-110.

36. TNA. FO. AB 61105. Visit of Señor MacVeigh to Atomic Construction Limited (14/8/1959); and AB 6591. British Embassy Report $(23 / 11 / 1962)$.

37. Catalan, J.: 'La ruptura de la posguerra y la industrialización, 19391975', in Nadal, J. (Dir.) Atlas de la industrialización de España, Barcelona: Crítica, 2003, pp. 233-88.

38. MacVeigh, J.: 'Posibilidades de la industria española en la construcción de centrales nucleares', in Conferencia Mundial de la Energía. Madrid, 5-9 June 1960.

39. For instance, in 1964 he participated in the annual meeting of the Atomic Industrial Forum in San Francisco, 'in which he acted as spokesman for European opinions on the new North American legislation regarding the private ownership of nuclear fuels and the enrichment of uranium under canon'. AHBBVA, Nuclenor Activity Report, 1965.

40. De la Torre, Joseba and Rubio-Varas, M.del Mar, 'Learning by doing: the first Spanish nuclear plant, Business History Review. 92, issue 1 (Spring 2018).

41. TNA, AB. 38,185. (27/09/1968). From 1962 to 1968 several meetings were held between the UKAEA and Tecnatom on business reprocessing. Ibidem. AB 38280.

42. ASEPI, Report about Tecnatom (8/3/1971). Tecnatom (2007).

43. It is well known that neither the competitive market nor technical practicality led to the dominance of American-made light-water reactors in electricity, isotope and plutonium production. Radkau, Joachim: 'Kernenergie-Entwicklung in der Bundesrepublik: ein Lernprozess. Die ungeplante Durchsetzung des Leichwasserreaktors und die Krise der 
gesellschaftlichen Kontrolle über die Atomwirtschaft, GG 4 (1978), pp. 195-222. Winnacker, Karl and Wirtz, Karl: Das unverstandene Wunder, Düsseldorf: Econ Verlag, 1975, pp. 192-193.

44. Wirtz's international activity in the 1960s and 1970s was intense. For example, in 1963, Wirtz participated in the Japan Atomic Industrial Forum and visited the Tokai nuclear research centre. That same year, he took part in the meeting of the United States Atomic Energy Commission (USAEC), GE and the Karlsruhe Nuclear Research Center (Kernforschungszentrum Karlsruhe; KfK), which were held in Arkansas. In 1966 and 1967, he attended the International Atomic Energy Association (IAEA) and the European Atomic Energy Society conferences in Sweden and Portugal. In 1969-1970, he spent a sabbatical at the University of Washington (Seattle). He regularly participated in the meetings of the American Nuclear Society, and in 1974 he was the coeditor of three specialized American journals. In 1975, he delivered a lecture in Mexico City and visited the Mexican National Institute of Nuclear Energy (Instituto Mexicano de Energía Nuclear). In addition, he maintained contact with experts in Brazil, Chile, Argentina and Venezuela. In 1976, he was preparing for a trip to Iran. Hermann, Armin: Karl Wirtz- Leben und Werk, Stuttgart: Schattauer, 2006, pp. 137-138,149,168-169. GLA Abt. 69/Kfk INR Nr. 52. Letter from Carlos Sánchez del Río to Karl Wirtz, 03.05.1967. GLA 69 KfK-INR Nr.168. Letter from K. Wirtz to Hans Frewer 13.07.1976.

45. GLA Abt. KfK, GF-1 Nr. 184. Brief z. Hdn. Karl Wirtz. Staatssekretär (Haunschlid). Bundesministerium für Bildung und Wissenschaft 17.08.1972. Brief (Kopie). z. Hdn. Staatssekretär (Haunschlid). KfK Karl Wirtz. 01.09.1972. Müller, Wolfgang D.: Geschichte der Kernenergie in der Bundesrepublik Deutschland, Stuttgart: Schäfer-Poeschel,1996, II. p. 127. GLA 69 KfK- GF1-Nr. 339,1. Letter from the President of the Nuclear Energy Board, Jesús Olivares, to Horst Böhm. 20.02.1979. GLA 69 KfK- GF1-Nr. 339,1. Dr. Nentwich. Internationale Beziehungen. Betr.: Besuch der JEN in der Zeit vom 4. bis 6. April 1979. 12.04.1979.GLA Abt.69 KfK-GF-1 Nr. 184. Letter from J.M. Otero to Hans-Hilger Haunschild. 18.09.1972. GLA Abt 69 KfKGF 1 Nr. 184. Notiz an Herrn Dr. Greifeld (Prof. Dr. K. Wirtz), 10.04.1972. Hermann, Karl Wirtz, pp. 33-42.

46. Hermann, Karl Wirtz, pp. 11,23, 65, 69. 
47. Stam, Thomas: Staat und Selbstverwaltung. Die Deutsche Forschung im Wiederaufbau 1945-1965, Köln: Verlag für Wissenschaft und Politik, 1981, p. 85. Keßler, G.: 'Zum Gedenken an Karl Wirtz', Physikalische Blätter 50. No. 9, (1994), p. 867. Hermann, Karl Wirtz, p. 77. Radkau, Joachim: Aufstieg und Krise der deutschen Atomwirtschaft 1945-1975, Reinbeck bei Hamburg: Rowohlt, 1983, p. 37.

48. Wirtz, Karl: Im Umkreis der Physik, Karlsruhe: KfK, 1988, p. 89. Hermann, Karl Wirtz, p. 137.

49. Law 25 of 29 April 1946 and Law 22 of 2 March 1950. Müller, Müller, Wolfgang D.:Geschichte der Kernenergie in der Bundesrepublik Deutschland, Stuttgart: Schäfer-Poeschel,1990, I. p. 43-54.

50. Radkau, Aufstieg und Fall, pp. 46. Winnacker and Wirtz, Das unverstandene, p. 90. Hermann, Karl Wirtz, p. 92.

51. Oetzel, Günther: Forschungspolitik in der Bundesrepubilk Deutschland. Entstehung und Entwicklung einer Institution der Großforschung am Modell des Kernforschungszentrums Karlsruhe KfK, 1956-1963, Frankfurt am Main: Peter Lang, 1996, pp. 11.12/24/84.

52. CSIC. International Conference on scientific research and energy problems. Madrid, 14-18 October 1974. Participant CV (Karl Wirtz). The conflicts were with engineers and scientists who served on corporate boards, such as Wolfgang Finkelnburg (Siemens), Rudolf Schulten (BBC/Krupp, later BBK) and Alfred Schuller (AEG). Oetzel, Forschungspolitik, p. 139. Müller, Geschichte, II. p. 342. Eckert, Michael Osietzki, Maria: Wissenschaft für Macht und Markt. Kernforschung und Mikroelektronik in der Bundesrepublik Deutschland, München: C.H. Beck, 1989, p. 84.

53. Sánchez Ron, José María: 'International Relations in Spanish Physics from 1900 to the Cold War', Historical Studies in the Physical and Biological Sciences, 33/1, (2002), pp. 3-31. Hermann, Karl Wirtz, p. 76-77-82.

54. Romero, Ana: 'Un viaje de José María Otero Navascués. Los inicios de la energía nuclear en España', Arbor, 659-660, (2000), pp. 509-526. Presas, Albert, 'La correspondencia entre José M. Otero Navascués y Karl Wirtz, un episodio de las relaciones internacionales de la Junta de Energía Nuclear' Arbor, 659-660, (2000), pp. 527-602. Romero de Pablos and Sanchez-Ron, De la JEN al CIEMAT, pp. 34-40,69,114. Hermann, Karl Wirtz, p. 81-82. 
55. The National Institute of Industry (INI), founded in 1941, was the holding of public companies where the state acted as an entrepreneur.

56. Aschmann, Birgit: 'Treue Freunde...? Westdeutschand und Spanien 1945-1963, Stuttgart: Franz Steiner Verlag, 1999, pp. 334-35. On the activities of the Spanish National Institute of Industry in Berlin during the Second World War, San Román, Elena: Ejército e industria: el nacimiento del INI, Barcelona: Crítica, 1999, pp. 200-204. On continuity and changes, Viñas, Ángel: Franco, Hitler y el estallido de la guerra civil, Madrid: Alianza, 2001, p. 517.

57. GLA Abt 69 KfK-INR. Nr. 52. High Council for Scientific Research. Alfonso X El Sabio Trust. Daza de Valdez Optics Institute. Applied Nuclear Physics Course. November 1950-July 1951. Madrid. Wirtz, Im Umkreis, pp. 87-88.

58. Wirtz, Im Umkreis, p. 87-88. Hermann, Karl Wirtz, p. 124. Aschmann, 'Treue Freunde...?? pp. 231-233.

59. Overbeck, Helmut: Der Schnelle Brüter in Kalkar. Planung, Bau, vornukleare Inbetriebnahme, Stilllegung, Düsseldorf: 1992, p. 48ff. Industrial partners in 1968 were Belgonucléaire, Neratom and Interatom who together created the INB company. Electric power industries (RWE, SEP and Synatom) formed the SBK company. Over the course of the 1960s, the French corporation EDF, the Italian public enterprise ENEL and the British CEGB became part of the project. Oetzel, Forschungspolitik, p. 242.Oetzel Günther: Die geplante Zukunft, Frankfurt am Main: Peter Lang, p. 99ff.

60. PAA B35 Band 77. Auswärtiges Amt. An den Bundesminister für wissenschaftliche Forschung. Betr: Zusammenarbeit mit Spanien auf dem Gebiet der Kernforschung und Kerntechnik, 12.12.1966.

61. GLA Abt. 69/Kfk INR Nr. 52. Letter from Carlos Sánchez del Río to Karl Wirtz, 03.05.1967. Consideration of Wirtz as an 'old friend of Spain' in communications between López Bravo and Gerhard Stoltenberg in 1966 in Aschmann, Birgit (1999), p. 233, note 222.

62. GLA Abt. 69/KfK INR Nr. 104. Besuch bei der Junta de Energía Nuclear in Madrid vom 10. bis 12. Sept. 1968 zwecks Vorbereitung der deutsch/spanischen Zusammenarbeit auf dem Gebiet der schnellen Brüter.

63. GLA. Abt. 69 KfK. PSB. Nr. 471. Zusammenstellung der durchgeführten Projekte bzw. laufenden Aktivitäten. Argentinien, Chile, Spanien, Pakistan, Rumänien. 15.03.1972. 
64. ASEPI. Box 4898. Minutes of the board of directors of Unión Eléctrica Madrileña, S.A (UEM) 29.01.1971/26.02.1971/24.10.1971. ASEPI. Box 4898. Note on the meeting of the board of directors of Unión Eléctrica Madrileña, S.A. (UEM), 20.01.1971/26.01.1971 On the visit of Giacomo Bertolotti Batistoni (Tecnatom) in the SBK in Essen ASEPI. Box 5048. Note on the meeting of the board of directors of Unión Eléctrica Madrileña, S.A. (UEM), 14.11.1972. GLA Abt. KfK, GF-1 Nr. 184. Vertrag zwischen der Projektgesellschaft Schneller Brüter GbR (PSB) und der Unión Eléctrica Madrileña, S.A. (UEM), 08.06.1971 (Madrid/Essen/ unsigned).

65. GLA Abt. 69 KfK INR Nr. 228. Handwritten agenda for Karl Wirtz's trip to Madrid 9.9.1968-12.09.1968. GLA Abt. 69 KfK INR Nr. 455. Spanish Government Nuclear Programme Project. Karl Wirtz. Madrid, 17.03.1969. GLA Abt. 69/KfK INR Nr. 57. Copy. Letter from Karl Wirtz to H. Schimmelbusch 16.09.1968.

66. GLA Abt. 69/KfK INR Nr. 104. Nuclear Programme and activities prepared for European Atomic Energy Society Meeting, Lugano, April 26-30, 1969, Madrid, April 1969, p. 3-4.

67. GLA Abt. 69/KfK INR Nr. 57. Letter from H. Schimmelbusch (NUKEM) to Karl Wirtz (INR), 03.09.1968 (Spanien). GLA Abt. 69/ KfK INR Nr. 104. Letter from Manuel Cortines (Chairman of IBERNUCLEAR S.A) to H.E. Schimmelbusch (NUKEM), 1.06.1968.

68. PA AA 129507 Brief und Anlage. Westdeutsche Landesbank Girozentrale (Düsseldorf) an das Chefs des Protokolls Auswärtiges Amt (Bonn) 4.2.1981. Lebenslauf (Dr. Ing. Julio Hernández Rubio) und Vorschlagsbegründung. GLA Abt. $69 \mathrm{KfK}$ INR Nr. 57. Letter from Carlos Sánchez del Río to Karl Wirtz, 6.5.1969. GLA Notiz (Wirtz). Zum Besuch der spanichen Delegation, 8. juli.1969. GLA Abt. 69 KfK INR Nr. 455 Notiz (Wirtz) Zum Besuch der spanischen Delegation am Dienstag 8. Juli 1969. GLA Internationales Büro. Dr. Schnurr. Dr. Laue. 4.8.1970. Betr: besuch den Herren Dr. Schnurr und Dr. Laue bei der Junta de Energía Nuclear, Madrid vom 15. bis 17.07.1970.

69. GLA Abt $69 \mathrm{KfK}-\mathrm{GF} 1 \mathrm{Nr}$. 184. Letter from José María Otero to H.E. Schimmelbusch 16.10.1972. GLA Abt 69 KfK-GF 1 Nr. 184. Bericht über einen Besuch bei der Junta de Energía Nuclear in Madrid, 22-11/24-11-1972. Schimmelbusch (NUKEM), Hildenbrandt (KWU), Warrikow (RGB) and Wirtz (GfK) participated. 
70. BNN 2.8.1973 Das kurze Interview: Es gibt kein Tabu. Geschäftsführer Dr. Rudolf Greifeld über Kooperation in der Kernforschung. GLA Abt. KfK, GF-1 Nr. 184.Kraftwerk Union Aktiengesellschaft zur GfK mbH z. H. Herrn Prof. Dr. Wirtz. Betreff KWU-Angebot an ENUSA über BE-Zusammenarbeit. Erlangen, 5. März 1973. Hilger, Susanne: 'Amerikanisierung' deutscher Unternehmen. Wettbewerbsstrategien und Unternehmenspolitik bei Henkel, Siemens und Daimler-Benz (1945/491975), Stuttgart: Franz Steiner Verlag, 2004, pp. 61ff.

71. Sanz Lafuente, Gloria: 'The Long Road to the Trillo Nuclear Power Plant' in Rubio-Varas M.d.M. and J. De la Torre (eds.), The Economic History of Nuclear Energy in Spain: Governance, Business and Finance. London: Palgrave Macmillan, 2017, pp. 187-215.

72. GLA 69 KfK-INR Nr.168. Letter from K. Wirtz to Hans Frewer 13.07.1976. Letter from Hans Frewer to Karl Wirtz, 18.08.1976. 